\title{
RESPONS MUHAMMADIYAH MENGHADAPI COVID-19
}

\author{
Falahuddin \\ UIN Mataram \\ falah.umm.lsi@gmail.com
}

\section{Abstrak}

Covid-19 telah menjadi wabah pandemi global. Virus tak kasat mata ini tidak hanya mengancam keselamatan jiwa manusia saja, tetapi juga telah memorakporandakan sektor ekonomi dan sosial secara luas. Untuk meminimalisir dampak Covid-19, semua kalangan dituntut untuk berperan aktif dan nyata dalam mengatasinya, termasuk Muhammadiyah. Dengan seluruh sumber daya yang dimiliki, Muhammadiyah telah berikhtiar secara maksimal untuk berkontribusi dalam penanganan Covid-19. Muhammadiyah telah membentuk semacam gugus tugas bernama Muhammadiyah Covid-19 Command Center (MCCC) yang menjadi garda terdepan dalam penanggulangan Covid-19 di tanah air. Selain itu juga, Muhammadiyah mendukung kebijakan-kebijakan pemerintah dalam menjalankan protokol kesehatan dalam rangka pencegahan penularan Covid-19, terutama terakit dengan pemberlakukan social/physical distancing.

Kata kunci: Respons, Muhammadiyah, Covid-19

\section{Pendahuluan}

Bermula dari kota Wuhan, Provinsi Hubei, Tiongkok pada Desember 2019, sejumlah pasien mendatangi rumah sakit pusat kota itu dengan membawa keluhan penyakit yang belum pernah dikenal. Dari hasil investigasi kemudian dilaporkan bahwa penyakit itu berasal dari virus, yang oleh Komite Internasionl untuk Taksonomi Virus (ICTV) memberinya nama Severe Acute Respiratory Syndrome Coronavirus 2 (SARS-Cov-2), dan oleh WHO penyakitnya diberi nama 
Covid-19, yang merupakan singkatan dari Coronavirus Disease 2019.293 Sejak itulah, korban massal berjatuhan di Wuhan akibat terinfeksi Covid-19 ini. Lalu diikuti jutaan korban jatuh berikutnya dengan cepat terjadi di seluruh dunia. Yang paling menyedihkan adalah diantara korban tersebut terdapat tenaga medis yang seharusnya menjadi ujung tombak penanganan Covid-19 ini. Hingga tulisan ini dibuat, minimal telah tercacat sebanyak 198 negara telah terkonfirmasi terpapar Covid-19, termasuk Indonesia yang terkonfirmasi pertama kali tanggal 2 Maret 2020.

Melihat eskalasi korban yang begitu meningkat tajam, pada 12 Maret 2020 dirjen WHO, dr. Tedros Adhanom Ghebreyesus, mengumumkan bahwa organisasi kesehatan dunia tersebut telah menetapkan Covid-19 sebagai wabah pandemik global. Meskipun masih satu genom (gugus) dengan SARS dan virus korona yang lain, karakteristik Covid-19 sepuluh kali lebih mematikan daripada virus flu babi (H1N1). ${ }^{294}$ Dalam pandangan WHO, status pandemi global ditetapkan terhadap Covid-19 merujuk kepada 3 hal, yaitu: Pertama, proses penyebaran virus baru ini begitu cepat dan mudah. Kedua, virus ini tidak mudah terdeteksi, sehingga penyebarannya pun sulit dikontrol. Ketiga, sikap dan kebiasaan masyarakat yang menganggap ringan dan remeh terhadap potensi penyebaran serta resiko akibat infeksi virus ini. ${ }^{295}$

Virus ini memang telah menjadi momok yang sangat menakutkan. Bagaimana tidak, virus yang tidak kasat mata ini menyerang siapa saja tanpa tebang pilih; tidak pandang usia, jabatan, status sosial dan seterusnya. Sebanyak 34 provinsi yang ada di Negara kita terkonfirmasi telah terinfeksi virus dengan tingkat pandemik yang berbeda-beda. Karena efeknya yang dahsyat itu, Covid-19 telah memorak-porandakan terutama sektor ekonomi dan sosial. Menteri Tenaga Kerja mengonfirmasi sebanyak 1,943,916 pekerja telah kehilangan pekerjaan sekaligus penghasilannya, karena dirumahkan dan di-PHK akibat Covid-19. 296 Prof. Asep Syaifuddin, guru besar IPB, mewanti-wanti, jika Covid-19 sampai Desember 2020 tidak terbendung, maka dampaknya melebihi krisis ekonomi, dan negara kita bisa terancam kolaps. ${ }^{297}$ Bahkan dapat berimbas kepada krisis

293. Yuli Nurhanisah, M. Ishaq Dwi Putra, "Mengenal Hubungan Vovid-19 dan SARS-CoV-2", Indonesiabaik. id. accessed April 26, 2020.

294. Rolando Fransiscus Sihombing, "WHO: Virus Corona 10 kali Lebih Mematikan dari Flu Babi", m.detik.com, accessed April 27, 2020.

295. "WHO Tetapkan Wabah Virus Corona Sebagai Pandemi Global", https://www.kompastv, accessed April 27, 2020.

296. Muhammad Hendarjo, “Dampak Corona, 1,9 Juta Pekerja Kena PHK dan Dirumahkan”, https:// bisnistempo.co, accessed April 27, 2020.

297. "Menurut Prof Asep Syaifuddin, Indonesia Terancam Kolaps", https://JPPN.com, accessed April 28, 2020. 
politik seperti tahun 1998. Apalagi WHO memprediksi negara kita dapat saja menjadi episentrum baru penyebaran Covid-19, jika tidak dikontrol secara ketat. ${ }^{298}$

Melihat dampak yang begitu serius, berbagai upaya memang telah dilakukan dalam rangka mengatasi Covid-19. Meskipun dianggap terlambat, pemerintah kita dengan berbagai kebijakan telah berupaya keras menghalau virus ini. Sejak 14 Maret 2020 Pemerintah menetapkan kebijakan Covid-19 sebagai Bencana Nasional. Lalu pada 17 Maret Pemerintah menetapkan Status Darurat Tanggap Bencana Korona hingga 29 Mei. Kemudian pada 31 Maret menetapkan Status Darurat Kesehatan Masyarakat. Terakhir, berbeda dengan beberapa Negara yang memberlakukan lockdown, dengan berbagai pertimbangan, Pemerintah kita memilih menetapkan kebijakan Pembatasan Sosial Berskala Besar (PSBB) untuk mencegah dan mengatasi penyebaran virus ini.

Terhadap kondisi darurat saat ini, seluruh elemen masyarakat, tidak terkecuali Muhammadiyah, dituntut berperan aktif dalam mengahadapi dan melawan Covid-19. Simpul-simpul sosial harus bersatu padu dan tidak boleh berpangku tangan serta pasrah menghadapi masalah besar ini. Semuanya harus bersatu padu melawan Covid-19. Partisipasi ini sangat penting, karena kunci pokok untuk memutus mata rantai penyebarannya ada pada masyarakat.

\section{Muhammadiyah dan Misi Kemanusiaan}

"Muhammadiyah selalu hadir ketika bangsa dan kemanusiaan semesta memanggil kala ada masalah. Demikian halnya ketika pandemi Covid-19 menjadi musibah yang melanda Indonesia dan dunia”. Demikian cuplikan tulisan Hadar Nashir, Ketua Umum PP Muhammadiyah di harian Republika. ${ }^{299}$ Pernyataan ini mengisyaratkan 2 hal: Pertama, hidup umat manusia di dunia ini selalu dilewati dan dipenuhi oleh aneka bencana. Bencana telah menjadi bagian dari sunnatullah dalam kehidupan ini yang tidak dapat ditolak, tetapi pada saat yang sama juga harus dihadapi. Kedua, komitmen Muhammadiyah yang selalu terlibat aktif dalam misi kemanusiaan.

Secara historis, atensi Muhammadiyah terhadah misi kemanusiaan sebenarnya berawal dari ide H. M. Syuja' yang ia sampaikan pada "Perkumpulan/Pengajian Malam Jumat" tahun 1917. Misi kemanusiaan itu kemudian dilembagakan

298. Haryanti Puspa Sari, “Indonesia Disebut Berpotensi Jadi Episentrum Baru Covid-19, Ini Respons Jubir Pemerintah" https://nasional.kompas.com, accessed April 27, 2020.

299. Haedar Nashir, "Kiprah Muhammadiyah”, Republika, Jumat, 17 April 2020. 
menjadi Bagian Penolong Kesengsaraan Umum/Oemoem yang kini dikenal dengan nama populer Rumah Sakit PKU/PKO Muhammadiyah. ${ }^{300}$ Namun dalam praktiknya, misi kemanusiaan yang diemban oleh PKU saat itu masih terbatas untuk melayani para kaum dhuafa secara sentralistik di PKO.

Dalam perkembangannya, misi kemanusiaan ini kemudian diperluas dengan terjun langsung ke lokasi-lokasi bencana. Misi kemanusiaan yang dibawa oleh Muhammadiyah tidak memandang latar belakang dan perbedaan agama, etnis, dan perbedaan lainnya, yang kadang menjadi penghalang dalam memberikan bantuan. Muhammadiyah memandang bahwa semua orang yang terdampak bencana, siapapun dia, dari latar belakang apapun, harus dapat dibantu dan harus diberdayakan sehingga bisa hidup layak.

Menurut Budi Setiawan, Ketua Muhammadiyah Disaster Management Center (MDMC), awal mula kepedulian Muhammadiyah terhadap misi kemanusiaan terhadap korban bencana adalah saat meletus Gunung Kelud tahun 1919 yang memakan korban 5000 jiwa. Kemudian tahun 1963 terjadi letusan Gunung Agung yang bertepatan dengan Tanwir Muhammadiyah. Dalam Sidang Tanwir tersebut disepakati agar dibentuk Gugus Tugas untuk menangani korban bencana. Sejak saat itu hingga kini Muhammadiyah secara aktif terlibat dalam misi kemanusiaan, tidak hanya di tingkat lokal, tetapi juga pada tingkat global. ${ }^{301}$ Di tingkat lokal, Muhammadiyah telah terjun dalam misi kemanusiaan saat gempa dan tsunami Aceh 2004, gempa Yogyakarta 2006, gempa Bengkulu dan padang 2007, banjir Masior di Papua 2010, gunung Rokatenda NTT meletus, konflik Syiah di Sampang 2012, gempa Lombok dan Donggala, Palu 2018, banjir bandang di Lebak, Banten 2019 dan Covid-19 pada 2020 ini. Pada tingkal global Muhammadiyah mengirimkan bantuan logistik, obat-obatan dan tenaga medis saat terjadi gempa di Nepal 2015, kriris kemanusiaan di Rakhine, Myanmar 2017 dan lainnya. Hal ini membuktikan bahwa Muhammadiyah sangat concern terhadap misi kemanusiaan.

Untuk menopang misi kemanusiaan ini, Muhammadiyah telah membentuk lembaga khusus yang bernama Lembaga Penanggulangan Bencana (LPB) atau Muhammadiyah Disaster Management Center (MDMC). Lembaga ini di-back-up oleh LAZIZMU (Lembaga Amil Zakat, Infaq dan Shadaqah Muhammadiyah) bersama semua komponen organisasi struktural dan Amal Usaha Muhammadiyah, terutama oleh ribuan tenaga medis yang tersebar di

300. M. Yusron Asrafie, Kiyai Haji Ahmad Dahlan: Pemikiran dan Kepemimpinannya, (Yogyakarta: MPKSDI, 2005), h. 94.

301. "Misi Kemanusiaan Kontemporer", https://www.suaramuhammadiyah.id, acsessed April 29, 2020. 
457 Rumah Sakit dan Rumah Bersalin di seluruh Indonesia dan para ilmuan dari 173 Perguruan Tinggi Muhammadiyah dengan latar belakang disiplin ilmu pengetahuan yang beragam. ${ }^{302}$

\section{Teologi Covid-19}

Wabah Covid-19 termasuk bencana nasional, bahkan global. Menurut Undangundang No. 24 tahun 2007, bencana adalah peristiwa atau rangkaian peristiwa yang mengancam dan mengganggu kehidupan dan penghidupan masyarakat yang disebabkan, baik oleh faktor alam dan/atau faktor non-alam maupun faktor manusia sehingga mengakibatkan timbulnya korban jiwa manusia, kerusakan lingkungan, kerugian harta benda dan dampak piskologis. ${ }^{303}$ Karena itu, Muhammadiyah memandang bahwa Covid-19 merupakan kategori bencana non-alam. ${ }^{304}$

Dalam memandang bencana, Muhammadiyah selalu mempertautkan antara teks-teks normatif dalam al-Qur'an dan Hadis dengan ilmu pengetahuan modern. Sebagai ormas yang mengusung jargon tajdid, cara pandang Muhammadiyah dalam melihat realitas sosial, termasuk Covid-19, selalu menggunakan pendekatan integratif: bayani, burhani dan irfani. ${ }^{305}$ Muhammadiyah menolak pandangan atomistik dan parsial, apalagi irrasional yang berpandangan bahwa bencana terjadi karena hal-hal yang berbau mistik yang tidak ada hubungannya dengan bencana.

Muhammadiyah memandang bahwa bencana terjadi karena 2 hal: Pertama, sunnatullah. Bencana terjadi karena proses alamiah sebagai bagian dari cara alam berevolusi secara terus-menerus sejak pertama kali alam diciptakan. Gempa dan tsunami misalnya yang kerap terjadi di negara kita, disebabkan oleh pergeseran lempeng bumi. Demikian juga gunung meletus disebabkan oleh peningkatan tekanan perut bumi. Kedua, bencana karena perilaku manusia yang mengeksploitasi alam raya secara berlebihan, kesalahan teknologi akibat human error dan lainya tanpa kalkulasi yang matang. ${ }^{306}$

302. PP Muhammadiyah, "Laporan PP Muhammadiyah saat Muktamar Muhammadiyah ke-47 di Maksassar, 16-22 Syawal/3-7 Agustus 2015", h. 23. www.muhammadiyah.or.id, accessed April 29, 2020.

303. Lihat Undang-undang Nomor 24 tahun 2007.

304. Majelis Tarjih dan Tajdid PP Muhammadiyah, Fikih Kebencanaan: Keputusan Musyawarah Nasional Tarjih ke-29 Tahun 2015 di Yogyakarta, (Yogyakarta: Majelis Tarjih dan Tajdid PP Muhammadiyah dan Lembaga Penanggunaangan Bencana PP Muhammadiyah, 2015), h. 41.

305. Lihat "Hasil Munas Jakarta: Manhaj Tarjih dan Pengembangan Pemikiran Islam", Suara Muhammadiyah, NO. 15 dan 16, TH KE-85 (1-31 Agustus 2002).

306. Majelis Tarjih dan Tajdid PP Muhammadiyah, Fikih Kebencanaan, h. 11-36. 
Dalam perspektif al-Qur'an dan Hadis, bencana secara umum disebut dengan 10 terminologi, yaitu musibah (Q.S. al-Hadid [57]: 22-23), bala' (Q.S. al-A'raf [7]: 168\}, firnah (Q.S. , azab (Q.S. al-Sajdah [32]: 21-22), fasad (Q.S. al-Ruma [41]: 30), halak (Q.S. al-Qasas [28]: 78), tadmir (Q.S. al-Isra' [17]: 16), tanziq (Q.S. Saba' [34]: 18-19), iqab (Q.S. al-Nahl [16]: 126), nazilah (Q.S al-Hijr [15]: 90-91). Semua bencana yang terjadi dan mendatangkan gangguan serius bagi kehidupan manusia disebut musibah. Bencana yang terkadang mengakibatkan kerugian, kerusakan dan kehancuran disebut tadmir dan tanziq, dan jika berdampak terhadap instabilitas sosial seperti kerusuhan disebut fasad. Jika bencana menimpa manusia jahat yang berdosa dan selalu melanggar ketentuan Tuhan disebut 'iqab, nazilah, dan bahkan azab. Adapun jika yang terdampak bencana adalah orang-orang taat, saleh dan baik, maka disebut bala'. ${ }^{307}$

Dari penjelasan terminologi bencana sebagaimana dalam al-Qur'an dan Hadis tersebut, terminologi azab yang berarti siksa atau kutukan sering menjadi atensi kita. Apakah bencana alam seperti gempa bumi dan tsunami atau bencana nonalam seperti Covid-19 yang sedang terjadi saat ini termasuk azab yang berarti kutukan atau musibah? Kalau orang-orang saleh terinfeksi Covid-19 apakah termasuk azab? Tampaknya nalar kita berat menjawab ya. Karena itu, Haedar Nashir, Ketua Umum PP Muhammadiyah, memandang Covid-19 sebagai musibah dan bukan kutukan ${ }^{308}$ untuk menguji dan memperteguh keimanan kita. Pandangan Haedar ini juga selaras dengan pandangan Imam Besar Masjid Istiqlal, Nasaruddin Umar, bahwa Covid-19 adalah musibah dan bukan azab. ${ }^{309}$

Secara historis, Covid-19 bukan merupakan wabah pandemik baru dalam sejarah perjalanan hidup manusia. Virus serupa dengan karakteristik yang sama seakan mengulang siklus 100 tahunan pandemi dunia. Tercatat pada 1720 terjadi pandemi campak, kolera 1818, flu Spanyol 1920, dan Covid-19 pada 2020.310 Sangat mungkin akan muncul virus serupa dengan karateristik yang dapat sama atau berbeda di kemudian hari. Dalam al-Qur'an juga diceritakan tentang bagaimana Allah mengirimkan wabah taufan, belalang, kutu, katak dan

\footnotetext{
307. Majelis Tarjih dan Tajdid PP Muhammadiyah, Fikih Kebencanaan, h. 11-36.

308. Haedar Nashir, "Bersama Menghadapi Covid-19", Suara Muhammadiyah, NO. 07, TH KE-105 (1-15 April 2020). h. 1.

309. Andhika Prasetia, "Imam Besar Istiqlal Tegaskan Corona Bukan Azab, Ini Penjelasannya”. https://m.detik. com, accessed April 28, 2020.

310. Muhammad Subarkah, "Kisah Flu Spanyol Tahun 1918 di Hindia Belanda (1), https://republika.co.id, accessed April 20, 2020.
} 
darah kepada Fir'aun dan bala tentaranya. ${ }^{311}$ Demikian juga pada zaman Nabi Muhammad SAW pernah terjadi wabah pandemi tha'un (penyakit menular dan sangat mematikan). ${ }^{312}$

Secara teologis, Covid-19 harus dipandang dalam perspektif tauhid. Virus ini merupakan makhluk Allah yang juga selalu bertasbih dan mengagungkanNya, sebagaimana makhluk lainnya (QS. al-Isra' [17]: 44). Sebagai makhluk ciptaan Tuhan, virus ini juga bukan makhluk yang muncul secara tiba-tiba dan "kebetulan". Virus ini, dengan semua dampak yang mengikutinya, muncul dalam skenario Tuhan yang telah diputuskan dan ditetapkan di Lauh al-Mahfuz sebelum seluruh makhluk diciptakan (QS. al-Hadid [57]: 22).

Bagi orang beriman, Covid-19 yang diciptakan Tuhan tidaklah sia-sia tanpa hikmah (QS. Ali Imran [3]: 190-191). Hikmahnya antara lain agar manusia selalu mengingat kebesaran Tuhan dan tidak boleh sombong, karena menghadapai virus kecil yang tidak kasat mata, ternyata manusia tidak berdaya. Selain itu juga kita harus selalu menjaga kualitas hidup, menghindari kerusakan alam sekaligus mengingat tugas kosmik manusia sebagai pemakmur alam (Q.S. Hud [11]: 61). Meskipun mendatangkan banyak mudarat dan mafsadat, munculnya virus ini harus diyakini sebagai ujian dan cobaan bagi manusia (Q.S. Ali Imran [3]: 142). Tidak boleh dipersepsikan bahwa kerusakan yang ditimbulkan oleh virus ini sebagai manifestasi dari ketidakadilan Tuhan (Q.S Fushilat [41]: 46).

\section{Menghadapi Covid-19 adalah Jihad Kemanusiaan}

Dalam menghadapi semua musibah, termasuk wabah Covid-19 ini, agama mengajarkan untuk selalu membangun dan meneguhkan sikap optimimisme dan menghindari sikap putus asa (QS. al-Hijr [15]: 56), karena hal itu menjadi

311. Ayat tersebut adalah:

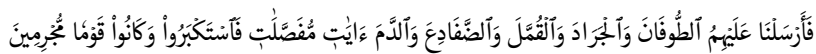

Maka Kami kirimkan kepada mereka taufan, belalang, kutu, katak dan darah sebagai bukti yang jelas, tetapi mereka tetap menyombongkan diri dan mereka adalah kaum yang berdosa. (Q.S al-A'raf [7]: 133.

312. Hadis tersebut adalah:

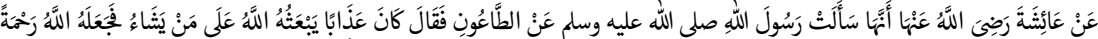

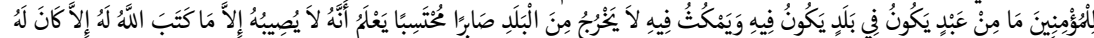

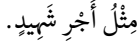

Dari Aisyah ra diceritakan ia bertanya kepada Rasulullah sawa tentang wabah tha'un. Lalu Nabi bersabda: Sesungguhnya wabah tha'un adalah ujian yang Allah kirimkan kepada siapa saja yang dikehendaki-Nya, dan Allah menjadikannya sebagai rahmat bagi orang-orang yang beriman. Tidaklah seorang hamba yang ketika di negarinya terjadi tha'un lalu tetap tinggal di sana dengan sabar dan mengharap pahala dari Allah, dan pada saat yang sama ia sadar bahwa tak aka nada yang menimpaanya selain telah digariskan-Nya, maka tidak ada balasan lain kecuali pahala seperti mati Syahid (HR. alBukhari). 
karakter orang yang tidak beriman (kafir) (QS. Yusuf [12]: 87). Manifestasi sikap optimisme adalah meyakini bahwa dampak Covid-19 yang begitu serius dalam kehidupan merupakan kesulitan yang pasti dapat dihadapi, karena Allah mengatakan: "pada setiap kesulitan pasti terdapat kemudahan" (Q.S. al-Insyirah [94]: 5). Jaminan Tuhan ini berlaku dengan syarat jika manusia memiliki inisiasi untuk terus berikhtiar mencari solusi bagi pencegahan Covid -19 dengan sungguh-sungguh (Q.S. al-Ra'ad [13]: 11) yang disertai dengan sikap sabar dan selalu mendekatkan diri kepada-Nya (Q.S. al-Baqarah [2]: ), bertaubat, membaca banyak istigfar, membaca al-Qur'an, berzikir, membaca kunut nazilah (tanpa bahasa kutukan dan semacamnya), banyak berselawat atas Nabi dan banyak berdoa. ${ }^{313}$

Dalam pandangan Muhammadiyah, partisipasi aktif semua pihak dengan segala cara dan sekecil apapun dalam rangka pencegahan Covid-19 bernilai ibadah dan dianggap telah berpartisipasi dalam jihad kemanusiaan. ${ }^{314}$ Saat pandemi Covid-19 seperti ini, Muhammadiyah memberikan tuntunan agar memperbanyak zakat, infak, dan sedekah serta memaksimalkan penyalurannya untuk pencegahan dan penanggulangan Covid-19 terutama kepada kelompok rentan dan terdampak lainnya, seperti untuk pembelian masker, hand sanitizer, sembako dan lainnya. ${ }^{315}$ Demikian sebaliknya, tindakan sengaja yang berdampak terhadap risiko penularan virus ini dianggap sebagai perbuatan zalim (Q.S. alMaidah [5]: 32). Sikap apatis dan abai terhadap Covid-19 dapat dianggap sebagai perlawanan terhadap larangan agama yang melarang manusia mencampakkan dirinya ke dalam jurang kebinasaan (Q.S. al-Baqarah [2]: 195).

Jika partisipasi aktif telah dilakukan dalam pencegahan Covid-19, namun masih ada korban yang jatuh, maka agama memandangnya meninggal dalam keadaan mati syahid. ${ }^{316}$ Demikian juga terhadap tenaga medis yang meninggal

313. Edaran PP Muhammadiyah Nomor 03/EDR/I.0/E/2020 Tentang Tuntunan Ibadah dalam Kondisi Darurat Covid-19, h. 29-32.

314. Muhammad Akbar, "Muhammadiyah: Tidak Mudik adalah Jihad Kemanusiaan", https://republika.co.id, accessed April 21, 2020.

315. Edaran PP Muhammadiyah, h. 24-25.

316. Hadis tentang hal tersebut adalah:

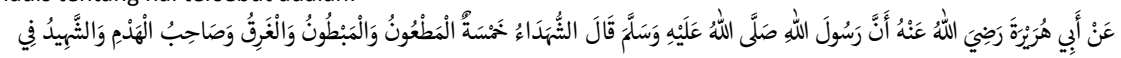

Dari Abu Hurairah diriwayatkan bahwa Rasulullah bersabda: orang syahid itu ada lima: orang yang terdampak wabah penyakit (tha'un), orang meninggal karena sakit di dalam perutnya, orang yang tenggelam, orang yang tertimpa reruntuhan bangunan. dan orang yang meninggaperang dijala Allah (HR. al-Bukhari). 
saat terlibat dalam upaya penyelamatan jiwa pasien positif Covid-19 dipandang meninggal dalam keadaan Syahid..$^{317}$

\section{Respons Muhammadiyah Menghadapi Covid-19}

Dalam merespons wabah Covid-19, Muhammadiyah telah mengeluarkan 2 Maklumat, 1 Edaran, 1 Surat Keputusan dan 1 Surat Pimpinan Pusat. Maklumat pertama terkait Covid-19 diterbitkan oleh Pimpinan Pusat Muhammadiyah pada tanggal 14 Maret 2020 dengan Nomor: 02/MLM/I.0/H/2020 tentang Wabah Corona Virus Disease (Covid-19). Tampaknya maklumat ini terbit setelah terjadi lonjakan pasien positif Covid-19 sebanyak 35 orang atau $1750 \%$ dalam tempo 11 hari dari yang semula berjumlah 2 orang pada saat diumumkan oleh Presiden Jokowi pada tanggal 2 Maret 2020.

Pada saat yang sama, pada 14 Maret 2020, Muhammadiyah menerbitkan Surat Keputusan Nomor2825/KEP/I.0/D/2020TentangPembentukanMuhammadiyah Covid-19 Command Center (MCCC) dengan tugas mengkoordinasikan berbagai program dalam rangka penanggulangan pandemik Covid-19. Muhammadiyah tampaknya telah mendapatkan informasi bahwa Covid-19 akan menjadi wabah pandemik dengan segala implikasi yang menyertainya.

Seiring berjalannya waktu, pelan tapi pasti, eskalasi pasien positif dari hari ke hari seakan tidak terbendung. Muhammadiyah mengeluarkan Maklumat ke-2 yang secara spesifik menghimbau agar Salat Jum'at diganti dengan salat zuhur dan Salat Jamaah Fardu di masjid agar dialihkan ke rumah masing-masing. Hal tersebut tertuang dalam Maklumat PP Muhammadiyah Nomor 3/I.0/B/2020 tertanggal 20 Maret tentang Penyelenggaraan Salat Jumat dan Salat Fardu.

Adapun Edaran PP Muhammadiyah Nomor 03/EDR/I.0/E/2020 Tentang Tuntunan Ibadah dalam Kondisi Darurat Covid-19 berisi tentang fatwa Majelis Tarjih dan Tajdid tentang hal yang sama dan diterbitkan sebanyak dua kali, pertama pada tanggal 24 Maret dan kedua pada tanggal 31 Maret. Edaran pertama diperuntukkan bagi kalangan internal Muhammadiyah, dan yang kedua juga untuk semua umat Islam. Pada 27 Maret 2020 telah terbit juga

317. Hadis tentang hal tersebut adalah:

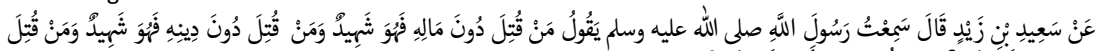

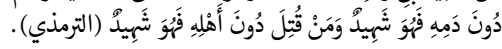

Dari Sa'id bin Zaid (ia meriwayatkan): Aku pernah mendegar Rasulullah saw pernah bersabda: Barangsiapa yang terbunuh karena melindungi hartanya maka dia syahid. Siapa yang terbunuh karena melindungi agamanya maka dia syahid. Siapa yang terbunuh karena melindungi darahnya maka dia syahid. Siapa yang terbunuh karena melindungi keluarganya maka dia syahid [HR al-Tirmidzi]. 
surat instruksi PP Muhammadiyah agar MCCC dibentuk di tingkat wilayah (provinsi).

Setelah memerhatikan kebijakan yang ditempuh oleh Muhammadiyah sebagaimana dalam Surat Keputusan dan Edaran tersebut, ada 3 kebijakan strategis yang ingin diambil oleh Muhammadiyah dalam menangani Covid-19, yaitu mengefektifkan social/physical distancning, pembentukan MCCC, dan bersinergi dengan pemerintah dan semua kalangan.

\section{Mengefektifkan Social Distancing (al-Taba'ud al-ljtima'i)}

Jargon Social Distancing atau Physical Distancing, Stay at Home, Work from Home, di rumah lebih baik, isolasi mandiri, isolasi kelompok dan mungkin ada jargon lainnya merupakan jargon-jargon yang paling akrab di telinga kita saat Covid-19 tengah menjadi wabah pandemik. Jargon-jargon ini pada intinya memberi pesan tentang pentingnya menjaga jarak fisik selama berinteraksi di tengah masyarakat sebagai pemutus mata rantai utama penyebaran Covid-19.

Untuk mengefektifkan implimenatasi social/physical distancing ini, Muhammadiyah menetapkan beberapa keputusan sebagai panduan khususnya bagi warga Muhammadiyah sebagaimana berikut:

\section{a. Membatalkan Agenda Strategis Persyarikatan}

Untuk mengefektifkan social/physical distancing, Muhammadiyah menunda pelaksanaan Muktamar. Muktamar Muhammadiyah merupakan agenda rutin lima tahunan Muhammadiyah sebagaimana tertuang dalam AD/ ART Muhammadiyah. Muktamar merupakan agenda wajib dan strategis Muhammadiyah yang melibatkan jutaan orang baik sebagai anggota, peserta dan penggembira. Muktamar merupakan media konsolidasi organisasi, evaluasi program, perencanaan program dan terutama untuk suskesi kepemimpinan. Kegiatan ini awalnya akan dilaksanakan pada tanggal 1-5 Juli 2020. Namun karena pandemi Covid-19, muktamar ditunda dan akan dilaksanakan pada tanggal 24-27 Desember 2020 sebagaimana tertuang dalam Surat Keputusan Nomor 2894/KEP/I.0/B/2020. Penundaan muktamar ini dilakukan sebagai upaya preventif untuk mencegah penyebaran Covid-19. Keputusan ini pun sangat dimaklumi dan kemudian disepakati oleh Pimpianna Wilayah Muhammadiyah se-Indonesia melalui rapat pleno secara telekonferensi (teleconference) bersama Organisasi Otonom tingkat Pusat pada tanggal 21 Maret 2020.

Selain menunda agenda wajib, Muhammadiyah juga membatalkan seluruh kegiatan persyarikatan dari tingkat pusat hingga ranting. Di tingkat pusat 
misalnya, salah satu agenda rutin yang dibatalkan oleh Muhammadiyah adalah Pengajian Ramadan tahun 2020 di kampus Universitas Muhammadiyah Yogyakarta (UMY). Kegiatan yang diikuti oleh seluruh Pimpinan Wilayah Muhammadiyah se-Indonesia ini dijadikan terutama sebagai media peneguhan ideologi dan konsolidasi gerakan. Pembatalan tersebut tertuang dalam Surat Keputusan Nomor 132/I.0/A/2020, tanggal 13 Syakban 1441 H/06 April 2020 M. Demikian juga, kegiatan-kegiatan formal lainnya yang telah diagendakan oleh Majelis dan Lembaga, semuanya juga dibatalkan.

\section{b. Merekayasa Teknis Pelaksanaan Ibadah Mahdhah}

Sebagaimana diketahui, ibadah mahdhah adalah ibadah yang dilaksanakan dengan tata-cara khusus sebagaimana diajarkan oleh Allah atau Nabi Muhammad SAW. ${ }^{318}$ Dalam ibadah ini, tidak dibenarkan adanya kreativitas manusia, karena hal tersebut dipandang sebagi bid'ah. Karena itu, dalam konteks ibadah, semua ketetapan harus memiliki landasan tekstual dari al-Qur'an dan Hadis.

Dalam pandangan Muhammadiyah, ibadah salat fardu merupakan kewajiban mutlak yang tidak dapat ditawar-tawar. Salat fardu harus dilaksanakan dalam kondisi dan situasi apapun. Karena itu, agama mengajarkan tata cara salat pada saat dalam kondisi darurat, seperti saat pandemi Covid-19, yang mengharuskan social/physical distancing.

Muhammadiyah memandang bahwa pandemi Covid-19 telah mengubah situasi dari kondisi normal menjadi darurat dan membawa kepada kondisi uzur. Agar virus ini tidak tersebar, semua orang harus menjaga jarak dengan orang lain. Karena itu, Muhammadiyah mengeluarkan fatwa bahwa seluruh salat jamaah dialihkan tempatnya dari masjid ke rumah masing-masing, seperti salat fardu lima waktu dan salat tarawih. ${ }^{319}$ Adapun salat Jum'at diganti dengan salat zuhur di rumah masing-masing juga. ${ }^{320}$ Sedangkan salat jenazah diganti dengan salat gaib di rumah. Demikian juga pelaksanaan salat id beserta rangkaiannya seperti mudik ditiadakan.

Pengaturan tata cara salat ini dilakukan karena dilakukan secara berjamaah yang melibatkan konsentrasi banyak orang dan berpotensi keras sebagai

318. Pimpinan Pusat Muhammadiyah Majelis Tarjih, Himpunan Putusan Tarjih I, (Yogyakarta: Persatuan, t.t.), $h$. 276.

319. Edaran PP Muhammadiyah, h. 14.

320. Hal ini didasarkan pada kaidah:

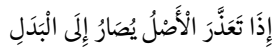

Apabila yang pokok tidak dapat dilaksanakan, maka beralih kepada pengganti [Syarh Manzuūmat alQawā'id al-Fiqhiyya (lihat Edaran PP Muhammadiyah, h. 17-18). 
media penyebaran virus ini. Karena itu, selama pandemi Covid-19 ini terjadi, pelaksanan salat Jum'at dan salat fardu berjamaah dan lainnya tidak perlu dilaksanakan di masjid atau lapangan. Hal ini didasarkan antara lain kepada postulat bahwa menghindari kemudaratan lebih diutamakan daripada mendatangkan maslahat. ${ }^{321}$ Juga didasarkan pada hadis yang menyatakan bahwa tidak ada kemudaratan dan pemudaratan; ${ }^{322}$ perintah agama dilaksanakan dengan mudah dan tidak boleh diberat-beratkan jika terdapat uzur, seperti saat pandemi Covid-19.323

Dalam konteks perawatan jenazah saat pandemi Covid-19, Muhammadiyah berpendapat agar dilakukan dengan memperhatikan protokol kesehatan. Jika dipandang darurat, untuk menghindari kontak langsung pihak keluarga ataupun tenaga medis dengan korban terpapar Covid-19, jenazah dapat dimakamkan tanpa harus dimandikan dan dikafani. Adapun salat jenazah dapat diganti dengan salat gaib, dan kegiatan takziah dapat dilaksanakan secara daring. ${ }^{324}$

Dalam konteks pernikahan, Muhammadiyah memandang penyelenggaraan akad nikah harus dilakukan dengan standar protokol kesehatan. Sedangkan walimatul urusy atau resepsi pernikahan ditiadakan atau ditunda sampai kondisi normal dan kondusif. 325

\section{Mendirikan MCCC (Muhammadiyah Covid-19 Command Center)}

Pembentukan MCCC merupakan partisipasi sekaligus kontribusi nyata Muhammadiyah dalam menghadapi Covid-19. Dalam Muhammadiyah, MCCC menjadi semacam gugus tugas atau lembaga ad hoc dalam menangani Covid-19 yang dibentuk melalui Surat Keputusan PP Muhammadiyah Nomor: 2825/KEP/I.0/D/2020 tanggal 15 Maret 2020. MCCC merupakan realisasi dari penugasan PP Muhammadiyah agar terjalin koordinasi antara Majelis

321. Kaidah tersebut adalah:

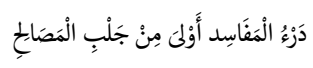

Menghindari kemudaratan lebih diutamakan dari mendatangkan maslahat (Lihat Edaran PP Muhammadiyah, h. 17-18).

322. Hal ini didasarkan pada hadis Nabi:

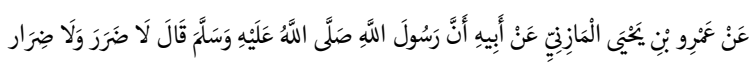

Dari Amr bin Yahya al-Mazani, dari ayahnya )ia menceritakan bahwa Rasulullah saw bersabda: tidak ada kemudaratan dan pemudaratan (HR. Malik dan Ahmad).

323. Hal ini didasarkan pada hadis Nabi:

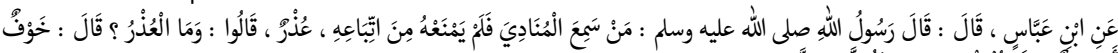

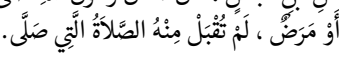

Dari Ibn 'Abbas (diriwayatkan bahwa) ia berkata: Rasulullah saw bersabda: Barangsiapa mendengar azan, lalu tidak ada uzur baginya untuk menghadiri jamaah -para Sahabat bertanya: Apa uzurnya? Beliau menjawab: keadaan takut dan penyakit-, maka tidak diterima salat yang dilakukannya (HR Abu Dawud).

324. Edaran PP Muhammadiyah, h. 26-29.

325. Ibid, h. 29. 
Pembina Kesehatan Umum (MPKU) dan Muhammadiyah Disaster Management Center (MDMC) atau Lembaga Penanggulangan Bencana (LPB). Dalam implementasinya, Tim MCCC berisi perwakilan dari LAZISMU, Diktilitbang, Dikdasmen, dan semua Ortom Muhammadiyah, termasuk Aisyiah. MCCC memiliki tugas pokok untuk menjalankan program-program pencegahan dan penanganan Covid-19.

Sebagaimana dalam penanganan bencana secara umum, MCCC melaksanakan tugasnya dalam 3 hal, yaitu [1] mitigasi dan kesiapsiagaan, [2] tanggap darurat, dan [3] recovery pasca bencana. ${ }^{326}$ Karena pandemi Covid-19 belum usai, MCCC untuk sementara ini memokuskan kegiatannya dalam 2 hal, yaitu:

Pertama, mitigasi dan kesiapsiagaan. Mitigasi dan kesiapsiagaan adalah tindakantindakan antisipatif dan preventif agar Covid-19 tidak semakin menyebar. Dalam konteks mitigasi dan kesiapsiagaan ini, MCCC secara aktif melakukan edukasi kepada masyarakat. Edukasi dianggap hal yang paling penting sebagai langkah awal pencegahan Covid-19 dilakukan baik secara langsung maupun melalui online. Edukasi langsung dilakukan dengan turun langung ke masyarakat untuk memberikan informasi yang cukup tentang Covid-19. Sedangkan edukasi online dilakukan dengan menyiapkan situs covid19.muhammadiyah.id yang dapat diakses oleh seluruh lapisan masyarakat untuk mendapatkan informasi dan layanan konseling tentang Covid-19. Hingga saat ini, MCCC telah melakukan sosialisasi dan edukasi untuk 12.650 orang, layanan diskusi online telah dimanfaatkan oleh 1.639 orang, layanan psikososial sebanyak 881 orang. ${ }^{327}$

Kedua, tanggap darurat, yaitu serangkaian kegiatan yang dilakukan dengan segera saat pandemi Covid-19 terjadi. Dalam laporan rutin tertanggal 27 April 2020, disebutkan bahwa MCCC telah menunjuk sebanyak 71 Rumah Sakit Muhammadiyah dan Aisyiah di seluruh Indonesia sebagai tempat rujukan pasien Covid-19 dengan rincian: 2.429 pasien ODP, 943 pasien PDP, dan 71 pasien positif Covid-19.328

Untuk mencegah penularan Covid-19, kepada penerima manfaat, MCCC telah mendistribusikaan 221.821 masker, 15.976 paket APD medis. MCCC juga telah membangun 26.252 titik penyemprotan dan 53.525 bilik disinfektan; membagi hand sanitizer untuk 55.250 jiwa dan disinfektan untuk 36.370 jiwa. Kepada

\footnotetext{
326. Majelis Tarjih dan Tajdid PP Muhammadiyah, Fikih Kebencanaan, h. 86.

327. Tim MCCC, "Laporan Penanganan Covid-19 Muhammadiyah, https://covid19.muhammadiyah.id, accessed April 27, 2020.

328. Ibid.
} 
masyarakat terdampak, MCCC telah menyalurkan bantuan sembako sebanyak 84.063 paket, dan makanan untuk 3.583 jiwa. ${ }^{329}$

Semua data yang ditampilkan di atas belum termasuk kontribusi yang berasal dari 29 Perguruan Tinggi Muhammadiyah (PTM) yang bernilai Rp. 24.972.662. 863,- untuk pembelian alat-alat medis, sembako, dan kebutuhan lainnya untuk menangani Covid-19. ${ }^{330}$

\section{Bersinergi dengan Pemerintah dan Semua Kalangan}

Kepada pihak eksternal, terutama pemerintah, Muhammadiyah mendorong agar dalam mengatasi wabah ini untuk bersinergi dengan semua pihak dan mengambil langkah serta kebijakan konkret yang akuntabel dan komprehensif. Adapun kepada internal, Muhammadiyah menginstruksikan agar kegiatan pendidikan pada semua tingkatan diselaraskan dengan kebijakan Pemerintah yang dikoordinasikan oleh majelis terkait. Kepada warga juga dihimbau agar senantiasa mengikuti dan menjalankan protokol kesehatan yang ditetapkan oleh pemerintah agar pandemi ini segera dapat berakhir.

\section{Penutup}

Sebagai salah satu ormas terbesar di Indonesia, Muhammadiyah telah memainkan perannya yang signifikan dalam menghadapi Covid-19. Muhammadiyah dengan seluruh sumber daya yang dimiliki bersama-sama pemerintah dan ormas lain telah berpartisipasi aktif dalam mengatasi wabah pandemik ini. Pembentukan Muhammadiyah Covid-19 Command Center (MCCC) dari tingkat pusat hingga wilayah (provinsi) di seluruh Indonesia sebagai bukti nyata bahwa Muhammadiyah tetap konsisten dan komitmen menjalankan misi kemanusiaan. Peran nyata Muhammadiyah, melalui MCCC, dalam menangani Covid-19 telah diapresiasi oleh pemerintah. Dalam konferensi pers pada 26 April 2020 saat menyampaikan progres Covid-19, juru bicara pemerintah pada Gugus Tugas Percepatan Penanganan Covid-19, dr. Achmad Yurianto, menyatakan bahwa MCCC telah menjadi salah satu garda terdepan dan menjadi patriot bangsa dalam menangani Covid-19, karena MCCC telah menerjunkan relawan-relawannya untuk melakukan layanan kesehatan dan melakukan edukasi tentang Covid-19, PSBB, isolasi mandiri dan kelompok. 


\section{Daftar Pustaka}

Akbar, Muhammad. "Muhammadiyah: Tidak Mudik adalah Jihad Kemanusiaan", https://republika.co.id, diakses pada 21 April 2020.

Asrafie, M. Yusron. Kiyai Haji Ahmad Dahlan: Pemikiran dan Kepemimpinannya, (Yogyakarta: MPKSDI, 2005).

Edaran Pimpinan Pusat Muhammadiyah Nomor 03/EDR/I.0/E/2020 Tentang Tuntunan Ibadah Dalam Kondisi Darurat Covid19-, tanggal 07 Sya'ban 1411 H/31 Maret $2020 \mathrm{M}$.

Hadis, dalam program maktabah syamilah.

"Hasil Munas Jakarta: Manhaj Tarjih dan Pengembangan Pemikiran Islam", Suara Muhammadiyah, NO. 15 dan 16, TH KE31-1) 85- Agustus 2002).

Hendarjo, Muhammad. "Dampak Corona, 1,9 Juta Pekerja Kena PHK dan Dirumahkan”, https://bisnistempo.co, accessed April 2020 ,27.

Majelis Tarjih dan Tajdid PP Muhammadiyah, Fikih Kebencanaan: Keputusan Musyawarah Nasional Tarjih ke29- Tahun 2015 di Yogyakarta, (Yogyakarta: Majelis Tarjih dan Tajdid PP Muhammadiyah dan Lembaga Penanggunaangan Bencana PP Muhammadiyah, 2015).

Maklumat Pimpinan Pusat Muhammadiyah Nomor 02/MLM/I.0/H/2020 Tentang Wabah Corona Virus Diesase (Covid19-), tanggal 19 Rajab 1411 H/14 Maret $2020 \mathrm{M}$.

Maklumat Pimpinan Pusat Muhammadiyah Nomor 03//I.0/B/2020 Tentang Penyelenggaraan Shalat Jum'at dan Fardu Berjamaah Saat Terjadi Wabah Corona Virus Diesase (Covid19-), tanggal 25 Rajab 1411 H/20 Maret 2020 M.

"Menurut Prof Asep Syaifuddin, Indonesia Terancam Kolaps", https://JPPN. com, accessed April 2020,28 .

"Misi Kemanusiaan Kontemporer", https://www.suaramuhammadiyah.id, acsessed April $2020,29$.

Nurhanisah, Yuli dan M. Ishaq Dwi Putra. "Mengenal Hubungan Vovid19- dan SARS-CoV2-”, Indonesiabaik. id. accessed April $2020,26$.

Nashir, Haedar. "Kiprah Muhammadiyah", Harian Republika, Jumat, 17 April 2020.

. "Bersama Menghadapi Covid19.", Suara Muhammadiyah, NO. 07, TH KE15-1) 105-April 2020).

Pimpinan Pusat Muhammadiyah Majelis Tarjih, Himpunan Putusan Tarjih I, (Yogyakarta: Persatuan, t.t.).

PP Muhammadiyah, "Laporan PP Muhammadiyah saat Muktamar Muhammadiyah ke47- di Maksassar, 22-16 Syawal/7-3 Agustus 2015", www.muhammadiyah.or.id, accessed April 2020 ,29. 
Prasetia, Andhika. "Imam Besar Istiqlal Tegaskan Corona Bukan Azab, Ini Penjelasannya”. https://m.detik.com, accessed April 2020 ,28.

Sari, Haryanti Puspa. "Indonesia Disebut Berpotensi Jadi Episentrum Baru Covid19-, Ini Responss Jubir Pemerintah” https://nasional.kompas. com, accessed April $2020,27$.

Sihombing, Rolando Fransiscus. "WHO: Virus Corona 10 kali Lebih Mematikan dari Flu Babi”, m.detik.com, accessed April 2020 ,27.

Subarkah, Muhammad. "Kisah Flu Spanyol Tahun 1918 di Hindia Belanda (1), https://republika.co.id, accessed April $2020,20$.

Surat Keputusan Pimpinan Pusat Muhammadiyah Nomor 2825/KEP/ I.0/D/2020 Tentang Pembentukan Muhammadiyah Covid19. Command Center, tanggal 19 Rajab $1411 \mathrm{H} / 14$ Maret $2020 \mathrm{M}$.

Surat Keputusan Pimpinan Pusat Muhammadiyah Nomor 2894/KEP/ I.0/B/2020 Tentang Perubahan Waktu Penyelenggaraan Muktamar Muhammadiyah ke48-dan Muktamar 'Aisyiah ke48-, tanggal 29 Rajab 1411 H/24 Maret $2020 \mathrm{M}$.

Surat Pimpinan Pusat Muhammadiyah Nomor 129/I.0/B/2020 Tentang Pembentukan MCCC di Tingkat Wilayah, tanggal 19 Rajab 1411 H/14 Maret $2020 \mathrm{M}$.

Tim MCCC, "Laporan Penanganan Covid19- Muhammadiyah, https:// covid19.muhammadiyah.id, accessed April 2020 ,27.

Undang-undang Nomor 24 tahun 2007 Tentang Penanggulangan Bencana.

"WHO Tetapkan Wabah Virus Corona Sebagai Pandemi Global", https:// www.kompastv, accessed April 2020 ,27. 